\title{
Striatal $\mathbb{D}_{1}$ and $\mathbb{D}_{2}$ receptor binding in patients with Huntington's disease and other choreas
} A PET study

\author{
N. Turjanski, ${ }^{1}$ R. Weeks, ${ }^{1}$ R. Dolan, ${ }^{2,3}$ A. E. Harding ${ }^{2}$ and D. J. Brooks ${ }^{1,2}$
}

${ }^{1} M R C$ Cyclotron Unit, Hammersmith Hospital, the

${ }^{2}$ Institute of Neurology and the ${ }^{3}$ Royal Free Hospital School of Medicine, London, UK
Correspondence to: Dr Nora Turjanski, MRC Cyclotron Unit, Hammersmith Hospital, Du Cane Road, London W12 OHS, UK

\section{Summary}

We have used PET to study striatal $D_{1}$ and $D_{2}$ receptor binding in 10 patients with either the choreic or akineticrigid variants of Huntington's disease and in three patients with other causes of chorea. Background rigidity and bradykinesia in choreic patients were scored with a fourpoint scale. PET studies showed a severe and parallel reduction of both striatal $D_{1}$ and $D_{2}$ receptor binding in Huntington's disease patients irrespective of their predominant phenotype (mean reduction 60\%). Huntington's disease patients with rigidity showed more pronounced reduction of striatal $D_{1}$ and $D_{2}$ binding compared with those without rigidity. A case of chorea associated with systemic lupus erythematosus had normal $D_{2}$ binding. These results suggest that the presence of chorea per se may not be determined by alterations in striatal dopamine receptor binding, but that rigidity in Huntington's disease is associated with severe striatal $D_{1}$ and $D_{2}$ receptor loss.

Keywords: Huntington's disease; chorea; systemic lupus erythematosus; PET; dopamine receptors

\section{Introduction}

Huntington's disease is an autosomal dominant disorder associated with behavioural changes, impaired cognition and a movement disorder which is usually chorea, but parkinsonism, dystonia and myoclonus may also occur (Folstein et al., 1986; Martin and Gusella, 1986; Young et al., 1986). The abnormal Huntington's disease gene (IT 15), containing an expanded number of CAG trinucleotide repeats, has now been identified on chromosome 4 (Huntington's Disease Collaborative Research Group, 1993). Post-mortem studies show marked atrophy of the neostriatum with a lesser degree of cell loss in the cerebral cortex, thalamus, globus pallidus and substantia nigra (Vonsattel et al., 1985; Martin and Gusella, 1986). Microscopically, there is pronounced loss of small spiny type II neurons from the striatum, accompanied by astrogliosis and preservation of larger aspiny interneurons (Roos, 1986). Cross and Rossor (1983) reported a $50 \%$ reduction of both $D_{1}$ and $D_{2}$ receptors in the putamen of 11 end-stage Huntington's disease patients examined at post-mortem, seven of whom were on treatment with neuroleptics. The clinical characteristics of these patients were not specified. Several in vivo PET and single photon emission computed tomgraphy (SPECT) studies have demonstrated reduced $D_{2}$ receptor binding in the putamen of choreic Huntington's disease patients (Wong et al., 1985; Leenders et al., 1986; Hagglund et al., 1987; Wienhard et al., 1990; Brucke et al., 1991; Antonini et al., 1992; Turjanski et al., 1993). Sedvall et al. (1994), using PET, reported a reduction in putamen $D_{1}$ receptor binding in a group of five Huntington's disease patients.

Current models of basal ganglia connectivity suggest that the main output of the striatum may be divided into a direct pathway that projects to the substantia nigra pars reticulata and the internal segment of the globus pallidus, and an indirect pathway which projects to the external segment of the globus pallidus, then the subthalamic nucleus and finally to internal segment of the globus pallidus (Gerfen, 1992). The internal segment of the globus pallidus and the substantia nigra pars reticulata are thus the final relay of the basal ganglia. Both the direct and indirect projections contain $\gamma$ aminobutyric acid (GABA), but the direct output is also rich in substance $P$ and dynorphine, while the indirect projections transmit enkephalin (Haber and Watson, 1985; Albin et al., 
1989; Graybiel, 1990; Gerfen, 1992). The exact distribution of dopamine $D_{1}$ and $D_{2}$ receptors amongst the cell bodies of striatal efferents is still controversial (Lester et al., 1993; Surmeier et al., 1993, 1994; Gerfen and Keefe, 1994). It has been suggested that substance P-containing neurons primarily bear $D_{1}$ sites, while neurons rich in enkephalin bear $D_{2}$ sites (Gerfen et al., 1990; Gerfen, 1992).

A post-mortem examination of patients with mild choreic variant of Huntington's disease have shown predominant loss of indirect striatal-external segment of the globus pallidus enkephalin containing projections, though loss of substance P-containing projections to substantia nigra pars reticulata was also noted (Albin et al., 1989). In patients with advanced disease or the severe akinetic-rigid variant, additional loss of the direct striatal substance P-containing projections to internal segment of the globus pallidus was found (Reiner et al., 1988; Albin et al., 1989). These findings have led to the suggestion that chorea may result from preferential damage of the indirect striatal projections to external segment of the globus pallidus, whilst the akinetic-rigid variant of Huntington's disease results from non-selective loss of all striatal projections to the external and internal segments of the globus pallidus (Albin et al., 1990; Hallett, 1993).

Combining the post-mortem findings in Huntington's disease with current concepts of basal ganglia connectivity, it might be predicted that patients with the choreic variant of Huntington's disease would show a preferential loss of striatal $D_{2}$ bearing neurons while patients with the akineticrigid variant would show a non-selective loss of both striatal $D_{1}$ and $D_{2}$ bearing neurons.

PET provides a means of exploring the neuropharmacology of the brain in vivo. The radioactive tracer ${ }^{11} \mathrm{C}$-raclopride is a selective reversible antagonist of $\mathrm{D}_{2}$ receptors while ${ }^{11} \mathrm{C}$ SCH 23390 is a selective antagonist of $D_{1}$ receptors. We have used PET and these two tracers to assess striatal $D_{1}$ and $\mathrm{D}_{2}$ dopaminergic receptor binding in a group of 10 nonneuroleptic treated Huntington's disease patients with either the choreic or the akinetic-rigid predominant phenotypes of Huntington's disease, two patients with sporadic chorea and a patient with chorea secondary to systemic lupus erythematosus.

\section{Patients and methods Patients}

Ten patients with Huntington's disease were studied with PET. Eight patients fulfilled diagnostic criteria for familial Huntington's disease (Martin and Gusella, 1986; Bateman et al., 1992). They had an adult onset autosomal dominant disorder with progressive chorea or an akinetic-rigid syndrome associated with cognitive dysfunction. DNA was available for four of these patients and analysis confirmed the diagnosis of Huntington's disease. In a further patient, paternal autopsy findings indicated a diagnosis of Huntington's disease. In the remaining three, the clinical features of the index patient and their relatives were typical of Huntington's disease; the diagnosis was made by neurologists experienced in the assessment of Huntington's disease families (A.E.H. or D.J.B.). Two other cases with chorea had no history of affected relatives but were shown to have the Huntington's disease gene mutation.

We also studied two other patients with sporadic progressive chorea and cognitive dysfunction. One had a history of Sydenham's chorea in childhood and possibly represented a case of recrudescent chorea (Bateman et al., 1992). In the second the diagnosis remains unclear. Neither had the Huntington's disease mutation. These will be referred to as cases of sporadic chorea.

The patients' mean age at the time of the first PET scan was 48 (range 29-72) years; and the mean duration of the disease was $3(1-10)$ years. In the Huntington's disease group, seven out of the 10 patients had the chorea predominant phenotype, whilst three had the akinetic-rigid variant (Table 1). Bradykinesia and rigidity were rated in all patients using a four-point scale; chorea was scored as present or absent. All but one of the nine choreic patients showed bradykinesia while mild rigidity was present in four of them. Abnormalities of ocular movements (gaze impersistence, hypometric saccades, broken pursuit, difficulties initiating saccades) were present in nine of the 10 patients with Huntington's disease and in one of the two patients with sporadic chorea.

Five of the 10 Huntington's disease patients and both patients with sporadic chorea underwent formal psychometry. This confirmed mild to moderate intellectual decline (performance and verbal IQ). Of the remaining five Huntington's disease patients, three showed mild impairment of recent memory and attention and one patient was found to be mildly demented on bedside testing. Emotional disturbances including anxiety, depression and aggressiveness were seen in eight of the 10 Huntington's disease and one of the two patients with sporadic chorea.

Cerebral CT and MRI showed mild generalized cerebral atrophy in 10 patients. Atrophy of the head of the caudate was present in four out of 10 Huntington's disease patients. These findings were not formally quantified. One patient with sporadic chorea had evidence of a previous haemorrhagic stroke in the right parietal lobe on MRI.

None of the patients were receiving neuroleptics or dopaminergic drugs at the time of the study or had taken such agents during the previous 12 months.

We also studied a 26-year-old female with an 11-year history of systemic lupus erythematosus who developed generalized chorea at the age of 25 years.

All patients were studied with "C-raclopride. Seven of the 10 patients with Huntington's disease and the two with sporadic chorea were also studied with ${ }^{11} \mathrm{C}-\mathrm{SCH} 23390$.

The patients' ${ }^{11} \mathrm{C}$-raclopride PET results were compared with those obtained for a group of nine normal subjects with a mean age of $50(24-74)$ years while the ${ }^{11} \mathrm{C}-\mathrm{SCH} 23390$ 
Table 1 Summary of patients' clinical details

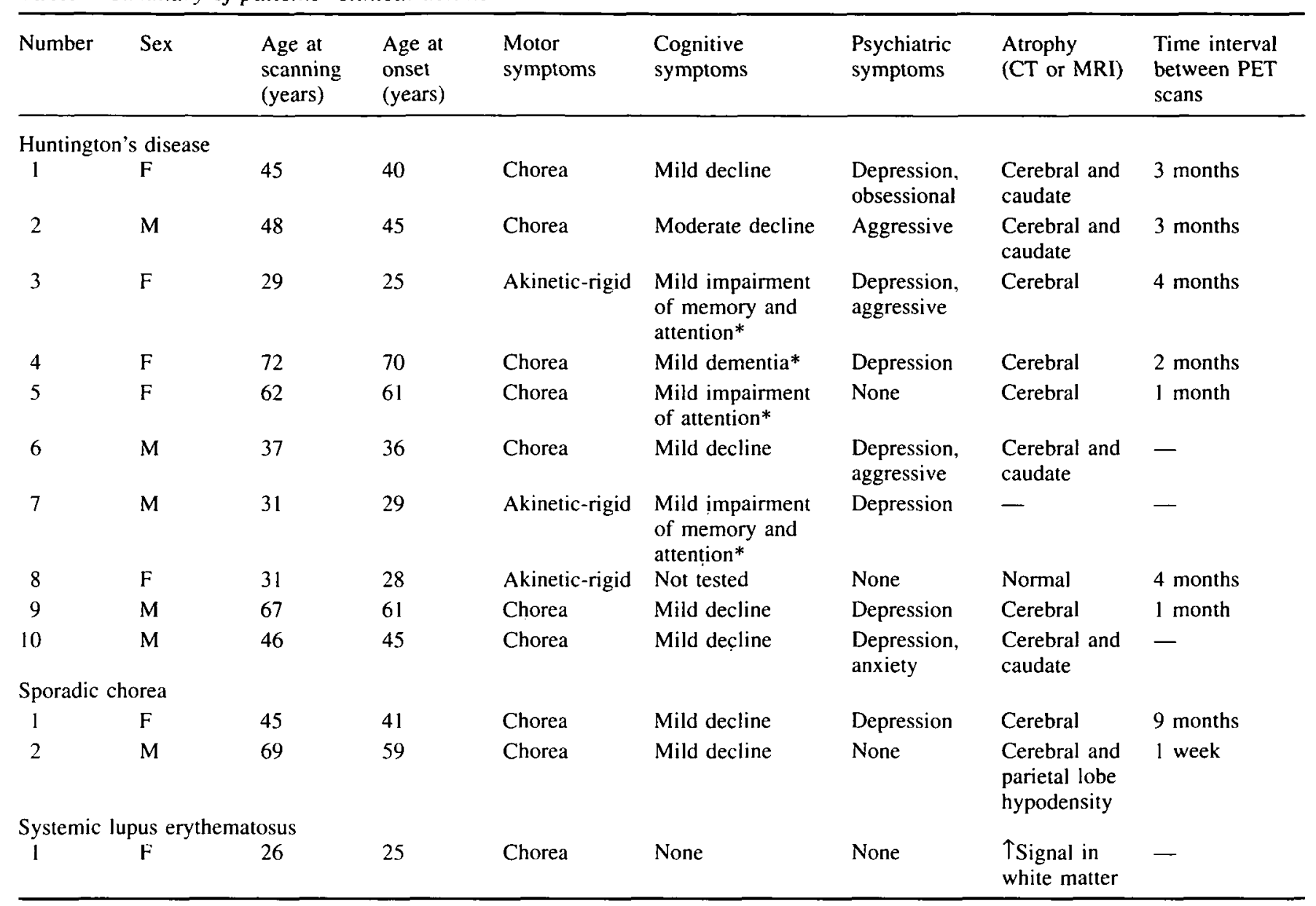

*Not formally tested.

results were compared with those obtained for a group of six normal subjects with a mean age of $51(31-78)$ years.

The ethical committee of the Royal Postgraduate Medical School, Hammersmith Hospital, approved this study. Permission to administer " $\mathrm{C}$-SCH 23390 and ${ }^{11} \mathrm{C}$-raclopride was obtained from the Administration of Radioactive Substances Advisory Committee of the UK (ARSAC). All subjects gave written informed consent.

\section{Methods}

Scan procedure

The ${ }^{11} \mathrm{C}$-raclopride PET scans were performed on a CTI $931 /-08 / 12$ scanner. The reconstructed spatial resolution of this scanner, for 15 simultaneously acquired slices, is 7.0 $\mathrm{mm}$ axially and $8.5 \times 8.5 \mathrm{~mm}$ transaxially (full width half maximum) (Spinks et al., 1988). The ${ }^{11} \mathrm{C}-\mathrm{SCH} 23390$ PET scans were done on a CTI/Siemens $953 \mathrm{~B}$ scanner. The reconstructed spatial resolution of this scanner, for 31 simultaneously acquired slices in $2 \mathrm{D}$ mode, is $4.3 \mathrm{~mm}$ axially and $8.5 \times 8.5 \mathrm{~mm}$ transaxially (full width half maximum) (Spinks et al., 1992). All PET studies were performed at the MRC Cyclotron Unit, Hammersmith Hospital, London, UK.
The patients' heads were immobilized while in the scanner using a polystyrene mould. Patients were aligned with the orbito-meatal line parallel to the detectors ring with the help of laser beams. A transmission scan was collected using a retractable external source of ${ }^{68} \mathrm{Ga} /{ }^{68} \mathrm{Ge}$ to correct for attenuation of $511 \mathrm{Kev} \gamma$-radiation by the brain and skull. The duration of the transmission scan was $10 \mathrm{~min}$ for the ${ }^{11} \mathrm{C}$ raclopride PET studies and $20 \mathrm{~min}$ for the ${ }^{11} \mathrm{C}-\mathrm{SCH} 23390$ PET. All medication was withdrawn for at least $12 \mathrm{~h}$ prior to PET.

${ }^{1}$ C-Raclopride. A mean dose of $288 \pm 110 \mathrm{MBq}$ of tracer, in $5 \mathrm{ml}$ of normal saline (mean specific activity $13989 \pm 8740$ $\mathrm{MBq} / \mu \mathrm{mol}$ ) was injected as a bolus. Scanning began after a 30 -s background frame, collecting a total of 22 serial time frames, increasing from $5 \mathrm{~s}$ to $10 \mathrm{~min}$ in duration, over a 60-min study period.

${ }^{11} \mathrm{C}-\mathrm{SCH} 23390$. A mean dose of $346 \pm 49 \mathrm{MBq}$ of tracer, in $5 \mathrm{ml}$ of normal saline (mean specific activity $22156 \pm 12064$ $\mathrm{MBq} / \mathrm{umol}$ ) was injected as a bolus. The scanning protocol was identical to the one described for ${ }^{11} \mathrm{C}$-raclopride. 
Table 2 Binding potentials for ${ }^{12} \mathrm{C}$-raclopride and ${ }^{\prime \prime} \mathrm{C}$-SCH23390

\begin{tabular}{|c|c|c|c|c|c|c|}
\hline & \multicolumn{3}{|c|}{${ }^{11} \mathrm{C}$-Raclopride } & \multicolumn{3}{|c|}{${ }^{11} \mathrm{C}-\mathrm{SCH} 23390$} \\
\hline & $n$ & $\begin{array}{l}\text { Caudate } \\
(\text { mean } \pm S D)\end{array}$ & $\begin{array}{l}\text { Putamen } \\
(\text { mean } \pm S D)\end{array}$ & $n$ & $\begin{array}{l}\text { Caudate } \\
(\text { mean } \pm S D)\end{array}$ & $\begin{array}{l}\text { Putamen } \\
(\text { mean } \pm S D)\end{array}$ \\
\hline Normal controls & 9 & $2.29 \pm 0.16$ & $2.35 \pm 0.13$ & 6 & $1.38 \pm 0.20$ & $1.35 \pm 0.14$ \\
\hline Huntington's disease & 10 & $0.84 \pm 0.26 * * *$ & $0.73 \pm 0.23^{* * *}$ & 7 & $0.52 \pm 0.20^{* * *}$ & $0.53 \pm 0.10^{* * *}$ \\
\hline Sporadic chorea & 1 & 1.80 & 1.75 & 1 & 1.43 & 1.32 \\
\hline Sydenham's recrudescence & 1 & 1.61 & 1.23 & 1 & 0.71 & 0.69 \\
\hline Systemic lupus erythematosus & 1 & 2.31 & 2.61 & & & \\
\hline
\end{tabular}

$* * * P<0.001$ after Bonferroni correction $(n=10)$.

The mean time interval between scans for the patients studied twice was 3 months (range 1 week to 9 months).

\section{Data analysis}

Image analysis was performed using Analyze software (version 6.1, BRU, Mayo Foundation, Rochester, Minn., USA) (Robb, 1990) on SUN Sparc2 computer workstations. Regions of interest were defined with reference to a stereotactic atlas using an image of integrated tracer activity collected during the last $40 \mathrm{~min}$ of scanning and by inspection of CT/MRI of the patients. Regions of interest were placed using a standard template arrangement (Brooks et al., 1990). One square region of interest, of a length of $8.2 \mathrm{~mm}$, was placed over the head of each caudate, while three square regions of interest, each of length $8.2 \mathrm{~mm}$, were placed contiguously over the dorsal putamen of each hemisphere. A further circular region of interest, of diameter $32.8 \mathrm{~mm}$ was placed over each cerebellar hemisphere. All regions of interest were defined in the two optimal adjacent planes. Time-activity plots were then obtained for each region of interest by projecting them on the dynamic time frames.

Regional time-activity curves were analysed using a reference tissue model with a cerebellar input function (Hume et al., 1992). This method measures the binding potential, a measure of the ratio of receptor density:dissociation constant $\left(B_{\max }: K_{\mathrm{d}}\right)$. Assuming that $K_{\mathrm{d}}$ is unaffected by pathology, it provides a measure of the number of available $D_{1}$ and $D_{2}$ receptors in caudate and putamen. This method has been validated for " $\mathrm{C}$-raclopride (Farde et al., 1986). Preliminary experiments (A. A. Lammertsma, personal communication) have confirmed that this reference tissue method can also be used for " $\mathrm{C}-\mathrm{SCH} 23390$.

"C-Raclopride and " $\mathrm{C}$-SCH23390 binding potentials for each group were compared with normals using Student's unpaired $t$ statistic, with a Bonferroni correction for multiple comparisons $(n=10)$. The correlations were calculated using Pearson product moment correlation test.

\section{Results}

\section{${ }^{\text {IC }}$-Raclopride results}

The Huntington's disease group of 10 patients showed a highly significant reduction of mean caudate ( $37 \%$ of normal,

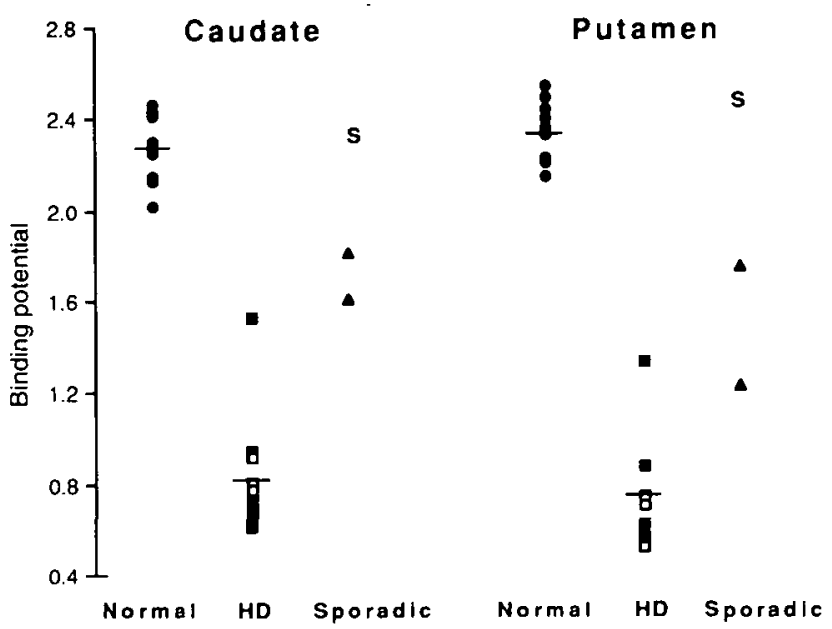

Fig. 1 A scatter diagram showing individual striatal

${ }^{11} \mathrm{C}$-raclopride $\mathrm{D}_{2}$ binding potentials of control subjects, patients with Huntington's disease (HD), patients with sporadic chorea, and a patient with systemic lupus erythematosus. Closed squares $=$ choreic; open squares = akinetic-rigid; $S=$ systemic lupus erythematosus.

$P<0.001)$ and putamen $(31 \%$ of normal, $P<0.001) \mathrm{D}_{2}$ binding potentials (Table 2). All individual Huntington's disease patients' results were reduced $>3$ SD below the normal mean, whether the patients were akinetic-rigid or choreic.

The two patients with sporadic chorea also had reduced caudate and putamen $\mathrm{D}_{2}$ binding potentials, but these were less affected than those of the Huntington's disease group. These two patients had had chorea for 4 and 10 years at the time of PET. The patient with systemic lupus erythematosis chorea had caudate and putamen binding potentials within the normal range (Fig. 1).

Figure 2 shows representative PET images of integrated striatal " $\mathrm{C}$-raclopride counts collected during the last $40 \mathrm{~min}$ of the study, for a normal subject and a patient with Huntington's disease.

Huntington's disease patients who showed rigidity (four with the choreic and three with the akinetic-rigid phenotype) had a significantly greater reduction of mean caudate and putamen $\mathrm{D}_{2}$ binding potentials than those without rigidity (see Fig. 3). 


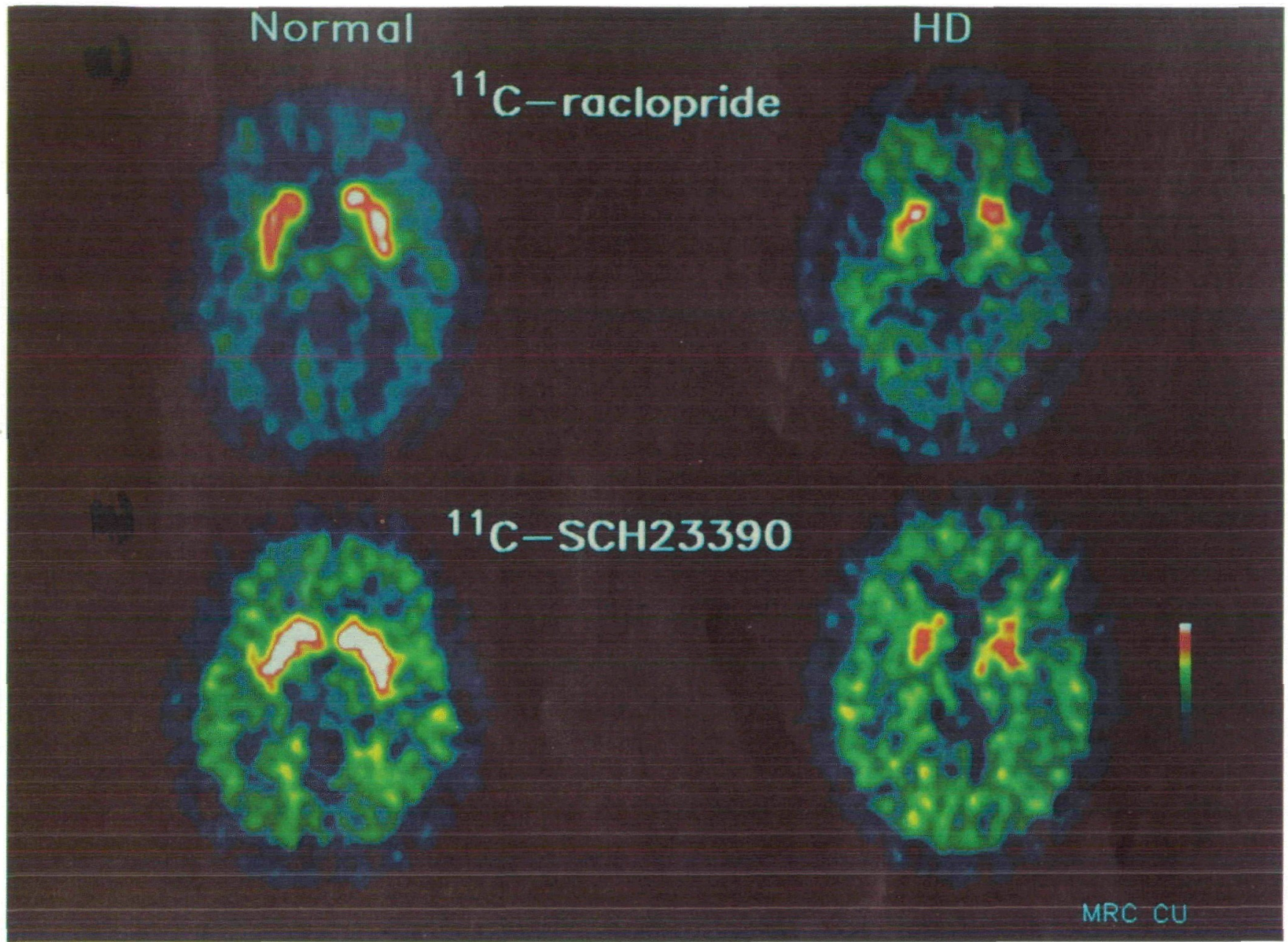

Fig. 2 PET images of integrated striatal ${ }^{11} \mathrm{C}$-raclopride and ${ }^{11} \mathrm{C}-\mathrm{SCH} 23390$ activity collected during the last 40 min of the scan for a normal subject and a choreic patient with Huntington's disease. A pronounced reduction of both caudate and putamen $D_{2}$ and $D_{1}$ binding is evident in Huntington's disease (HD).

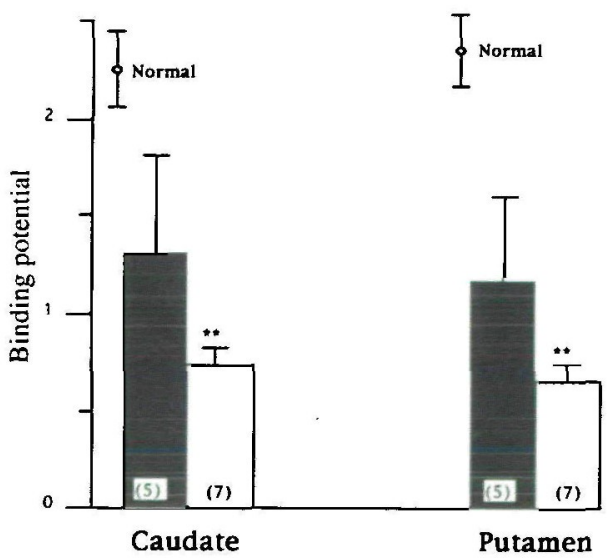

Fig. 3 A histogram of mean caudate and putamen $D_{2}$ binding potentials for patients with and without rigidity. Both groups showed significantly reduced caudate and putamen binding potentials compared with normal controls $(P<0.001)$. The number of patients is given in brackets; closed columns $=$ absence of rigidity; open columns $=$ presence of rigidity. $* * P<0.01$.

\section{${ }^{11} \mathrm{C}-\mathrm{SCH} 23390$ results}

The seven patients with Huntington's disease showed a significant reduction in mean caudate (38\% of normal, $P<0.001)$ and in mean putamen (39\% of normal, $P<0.001$ ) $D_{1}$ receptor binding potentials (Table 2 ). All individual values, with the exception of one patient's caudate, were reduced $>3 \mathrm{SD}$ below the normal mean, irrespective of whether they had a choreic or akinetic-rigid phenotype (Fig. 4).

Of the two mutation-negative sporadic chorea patients, one showed normal striatal $D_{1}$ receptor density, while the other (with a history of Sydenham's chorea) had caudate and putamen binding potentials $>3 \mathrm{SD}$ below the normal mean.

Figure 2 shows PET images of integrated striatal "CSCH23390 counts collected during 20-60 min after tracer infusion, for a normal subject and a patient with Huntington's disease.

Caudate and putamen $D_{1}$ and $D_{2}$ binding potentials were significantly correlated for the seven patients studied with both tracers: caudate $r=0.833$, putamen $r=0.877$ $(P<0.01)$. There was no significant correlation between $\mathrm{D}_{1}$ or $\mathrm{D}_{2}$ striatal receptor binding and duration of symptoms. 


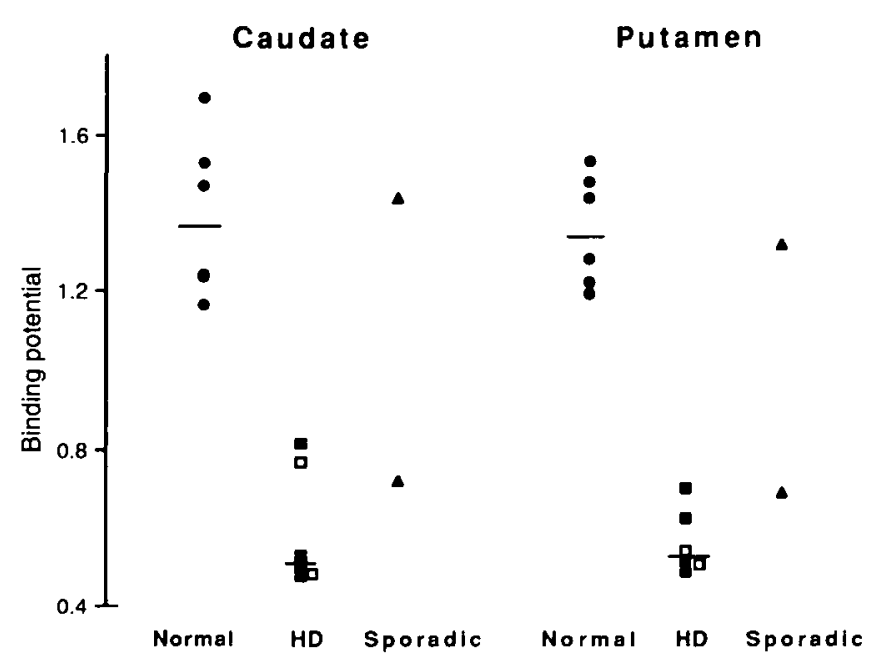

Fig. 4 A scatter diagram showing individual caudate and putamen "C-SCH23390 $\mathrm{D}_{1}$ binding potentials for Huntington's disease (HD), sporadic chorea, and normal controls. Closed squares $=$ choreic; open squares $=$ akinetic-rigid.

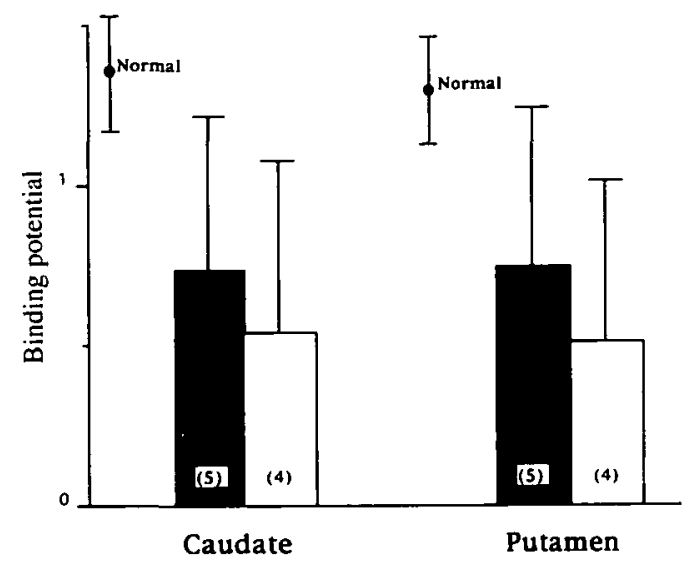

Fig. 5 A histogram of mean caudate and putamen $D_{1}$ binding potentials for patients with and without rigidity. Both groups showed significantly reduced caudate and putamen binding potentials compared with normal controls $(P<0.001)$. The number of patients is given in brackets; closed columns = absence of rigidity; open columns $=$ presence of rigidity.

Huntington's disease patients with rigidity showed a trend towards a greater reduction of striatal $D_{1}$ binding potentials than those without (see Fig. 5).

Only one of the 10 Huntington's disease patients had chorea without any rigidity or bradykinesia. This patient showed reductions of both striatal $D_{1}$ and $D_{2}$ receptor binding $>3$ SD below the normal mean.

\section{Discussion}

All patients with Huntington's disease showed significant and parallel reductions of striatal $D_{1}$ and $D_{2}$ receptor density, irrespective of the predominant clinical phenotype or duration of illness. The systemic lupus erythematosus patient had normal caudate and putamen $\mathrm{D}_{2}$ binding potentials, suggesting that chorea may occur without associated abnormalities of striatal $D_{2}$ receptor binding. The finding of reduced $D_{1}$ and $\mathrm{D}_{2}$ binding in the patient with probable recrudescence of Sydenham's chorea, suggests that persistent striatal damage can occur after this inflammatory disorder (Gibb and Lees, 1989).

Our PET findings are in agreement with previous postmortem data. A study on end-stage Huntington's disease patients, using $\left[{ }^{3} \mathrm{H}\right]$ spiperone to label $D_{2}$ receptors and $\left[{ }^{3} \mathrm{H}\right]$ piflutixol to identify $D_{1}$ receptors, reported a $50 \%$ reduction of binding of both these tracers in the putamen (Cross and Rossor, 1983). In this study, clinical details of the patients were not given and the majority were taking neuroleptics. Two other post-mortem series reported a greater reduction of striatal $D_{1}$ than $D_{2}$ receptor density in early Huntington's disease rather than the expected converse (Joyce et al , 1988; Richfield et al., 1991). As far as we are aware, there have been no studies formally measuring relative densities of striatal $D_{1}$ and $D_{2}$ receptors in untreated Huntington's disease patients separated into choreic and akinetic-rigid clinical phenotypes.

Although ours is the first PET study to correlate $D_{1}$ and $\mathrm{D}_{2}$ status in vivo in both clinical phenotypes of Huntington's disease, other neuropharmacological studies with PET have been performed. Patients with the choreic variant studied with ${ }^{18} \mathrm{~F}$-dopa and $\left[{ }^{11} \mathrm{C}\right]$ methylspiperone have shown functional integrity of nigrostriatal dopaminergic projections, but severely reduced striatal $\mathrm{D}_{2}$ binding (Leenders et al., 1986; Hagglund et al., 1987). Wong et al. (1985) found an inverse correlation between caudate $\mathrm{D}_{2}$ receptor binding and duration of illness in their group of 13 Huntington's disease patients; $\mathrm{D}_{2}$ binding was reported to be normal in nine at risk subjects. Other PET and SPECT reports have shown reductions in striatal $D_{2}$ binding in both Huntington's disease patients and relatives at high risk (Wienhard et al., 1990; Brucke et al., 1991; Antonini et al., 1992; Turjanski et al., 1993). Striatal $\mathrm{D}_{1}$ receptor binding has been reported to be reduced in five patients with choreic Huntington's disease and one asymptomatic gene carrier (Sedvall et al., 1994).

Digital read-out of MRIs were not available in our Huntington's disease patients and, consequently, formal coregistration with PET was not performed. Atrophy of the head of the caudate was seen in only four out of our 10 Huntington's disease patients, whilst all of them showed significantly reduced tracer binding. Caudate regions of interest were placed over identifiable caudate tissue with reference to $\mathrm{CT} / \mathrm{MRI}$ and it is unlikely that partial volume effects had a major influence on our PET findings.

All but one of our nine choreic patients had concurrent bradykinesia, while four showed rigidity. Neurophysiological studies have previously reported coexistence of bradykinesia in patients with choreic Huntington's disease (Thompson et al., 1988). Huntington's disease patients with rigidity showed a greater reduction in mean striatal $D_{1}$ and $D_{2}$ receptor binding than those without, though this only reached significance for $D_{2}$ receptor binding. If $D_{1}$ and $D_{2}$ receptors 
are indeed segregated to direct and indirect striatal projections, as has been suggested (Gerfen and Keefe, 1994), these findings indicate that rigidity is associated with non-specific loss of all striato-pallidal projections (Albin et al., 1990; Hallett, 1993). The presence of bradykinesia did not show any correlation with loss of either $D_{1}$ or $D_{2}$ receptor binding.

Our single Huntington's disease patient with isolated pure chorea showed severe reduction of both striatal $D_{1}$ and $D_{2}$ receptors. This again suggests that chorea was associated with non-selective loss of striatal projections. In keeping with the last viewpoint, recent post-mortem examinations (Storey and Beal, 1993) have failed to find selective loss of striatal enkephalin containing projections in early choreic Huntington's disease, striatal substance P-containing projections being equally affected. While we detected a mean $60 \%$ fall in the binding potential of both striatal $D_{1}$ and $D_{2}$ receptors populations in our Huntington's disease patients, this finding is not specific for this condition, as indicated by the results in the patient with a probable recrudescence of Sydenham's chorea. In a previous PET study of patients with chorea due to neuroacanthocytosis, we reported a similar reduction of striatal $\mathrm{D}_{2}$ binding (Brooks et al., 1991). This suggests that the presence of reduced striatal $D_{2}$ binding is not a useful discriminator of degenerative or inflammatory causes of chorea.

In summary, untreated patients with Huntington's disease show a severe parallel reduction of striatal $D_{1}$ and $D_{2}$ receptor binding irrespective of whether chorea or rigidity is predominant. Rigid Huntington's disease patients, however, show a greater loss of mean striatal $D_{1}$ and $D_{2}$ binding than those choreic patients without rigidity. A case of systemic lupus erythamatosus chorea showed normal striatal $D_{2}$ binding. These results suggest that the presence of chorea per se may not be determined by alterations in dopamine receptor binding, but that the rigidity in Huntington's disease is associated with striatal dopamine $D_{1}$ and $D_{2}$ receptor loss.

\section{Acknowledgements}

We wish to thank colleagues of the Chemistry and PET methods sections at the MRC Cyclotron Unit for their expert assistance, and also $\mathrm{Mr} \mathrm{A}$. Blyth, Mr G. C. Lewington and Mrs A. Williams for their help with scanning, and $\operatorname{Dr} \mathrm{M}$. B. Davis for DNA analysis.

\section{References}

Albin RL, Young AB, Penney JB. The functional anatomy of basal ganglia disorders [see comments]. [Review]. Trends Neurosci 1989; 12: 366-75. Comment in: Trends Neurosci 1990; 13: 93, Comment in: Trends Neurosci 1990; 13: 93-5.

Albin RL, Reiner A, Anderson KD, Penney JB, Young AB. Striatal and nigral neuron subpopulations in rigid Huntington's disease: implications for the functional anatomy of chorea and rigidityakinesia. Ann Neurol 1990; 27: 357-65.
Antonini A, Schmid W, Spiegel R, Leenders KL. Cerebral glucose metabolism and striatal dopamine receptor density measured with PET in subjects at risk for Huntington's disease [abstract]. Mov Disord 1992; 7 Suppl 1: 145.

Bateman D, Boughey AM, Scaravilli F, Marsden CD, Harding AE. A follow-up study of isolated cases of suspected Huntington's disease. [Review]. Ann Neurol 1992; 31: 293-8.

Brooks DJ, Salmon EP, Mathias CJ, Quinn N, Leenders KL, Bannister $\mathrm{R}$, et al. The relationship between locomotor disability, autonomic dysfunction, and the integrity of the striatal dopaminergic system in patients with multiple sytem atrophy, pure autonomic failure, and Parkinson's disease, studied with PET. Brain 1990; 113 : 1539-52.

Brooks DJ, Ibañez V, Playford ED, Sawle GV, Leigh PN, Kocen RS, et al. Presynaptic and postsynaptic striatal dopaminergic function in neuroacanthocytosis: a positron emission tomographic study. Ann Neurol 1991; 30: 166-71.

Brucke T, Podreka I, Angelberger P, Wenger S, Topitz A, Kufferle $B$, et al. Dopamine $D_{2}$ receptor imaging with SPECT: studies in different neuropsychiatric disorders. J Cereb Blood Flow Metab $1991 ; 11: 220-8$.

Cross A, Rossor M. Dopamine D-1 and D-2 receptors in Huntington's disease. Eur J Pharmacol 1983; 88: 223-9.

Farde L, Hall H, Ehrin E, Sedvall G. Quantitative analysis of $D_{2}$ dopamine receptor binding in the living human brain by PET. Science 1986; 231: 258-61.

Folstein SE, Leigh RJ, Parhad IM, Folstein MF. The diagnosis of Huntington's disease. Neurology 1986; 36: 1279-83.

Gerfen $\mathrm{C}$. The neostriatal mosaic: multiple levels of compartmental organization. Trends Neurosci 1992; 15: 133-9.

Gerfen CR, Keefe KA. Neostriatal dopamine receptors [letter; comment]. Trends Neurosci 1994; 17: 2-3. Comment on: Trends Neurosci 1993; 16: 299-305.

Gerfen CR, Engber TM, Mahan LC, Susel Z, Chase TN, Monsma $\mathrm{FJ} J r$, et al. $\mathrm{D}_{1}$ and $\mathrm{D}_{2}$ dopamine receptor-regulated gene expression of striatonigral and striatopallidal neurons [see comments]. Science 1990; 250: 1429-32. Comment in: Science 1991; 253: 332.

Gibb WR, Lees AJ. Tendency to late recurrence following rheumatic chorea. Neurology 1989; 39: 999.

Graybiel AM. Neurotransmitters and neuromodulators in the basal ganglia. [Review]. Trends Neurosci 1990; 13: 244-54.

Haber SN, Watson SJ. The comparative distribution of enkephalin, dynorphin and substance $P$ in the human globus pallidus and basal forebrain. Neuroscience 1985; 14: 1011-24.

Hagglund J, Aquilonius S-M, Eckemas S-A, Hartvig P, Lundquist H, Gullberg P, et al. Dopamine receptor properties in Parkinson's disease and Huntington's chorea evaluated by positron emission tomography using "C-N-methyl-spiperone. Acta Neurol Scand 1987; 75: 87-94.

Hallett M. Physiology of basal ganglia disorders: an overview. Can J Neurol Sci 1993; 20: 177-83.

Hume SP, Myers R, Bloomfield PM, Opacka-Juffry J, Cremer J, Ahier RG, et al. Quantitation of carbon-11 labeled raclopride in rat 
striatum using positron emission tomography. Synapse 1992; 12: $47-54$.

Huntington's Disease Collaborative Research Group. A novel gene containing a trinucleotide repeat that is expanded and unstable on Huntington's disease chromosomes [see comments]. Cell 1993; 72: 971-83. Comment in: Cell 1993; 72: 817-18.

Joyce JN, Lexow N, Bird E, Winokur A. Organization of dopamine $D 1$ and D2 receptors in human striatum: receptor autoradiographic studies in Huntington's disease and schizophrenia. Synapse 1988; 2: $546-57$.

Leenders KL, Frackowiak RSJ, Quinn N, Marsden CD. Brain energy metabolism and dopaminergic function in Huntington's disease measured in vivo using positron emission tomography. Mov Disord 1986; 1: 69-77.

Lester J, Fink S, Aronin N, DiFiglia M. Colocalization of $D_{1}$ and $\mathrm{D}_{2}$ dopamine receptor mRNAs in striatal neurons. Brain Res 1993; 621: 106-10.

Martin JB, Gusella JF. Huntington's disease. Pathogenesis and management. [Review]. N Eng] J Med 1986; 315: 1267-76.

Reiner A, Albin RL, Anderson KD, D'Amato CJ, Penney JB, Young AB. Differential loss of striatal projection neurons in Huntington disease. Proc Natl Acad Sci USA 1988; 85: 5733-7.

Richfield EK, O'Brien CF, Eskin T, Shoulson I. Heterogeneous dopamine receptor changes in early and late Huntington's disease. Neurosci Lett 1991; 132: 121-6.

Robb RA. A software system for interactive and quantitative analysis of biomedical images. In: Hohne KH, Fuchs H, Pizer SM, editors. 3D imaging in medicine: algorithms, systems, applications. NATO ASI, Series F, Vol. 60. Berlin: Springer-Verlag, 1990: 333-61.

Roos RAC. Neuropathology of Huntington's chorea. In: Vinken PJ, Bruyn GW, Klawans HL, editors. Handbook of clinical neurology, Vol. 49. Amsterdam: Elsevier Science, 1986: 315-26.

Sedvall G, Karlsson P, Lundin A, Anvret M, Suhara T, Halldin C, et al. Dopamine $D_{1}$ receptor numbe-a sensitive PET marker for early brain degeneration in Huntington's disease. Eur Arch Psychiatry Clin Neurosci 1994; 243: 249-55.

Spinks TJ, Jones T, Gilardi MC, Heather JD. Physical performance of the latest generation of commercial positron scanner. IEEE Trans Nucl Sci 1988; 35: 721-5.

Spinks TJ, Jones T, Bailey DL, Townsend DW, Grootoonk S, Bloomfield PM, et al. Physical performance of a positron tomograph for brain imaging with retractable septa. Phys Med Biol 1992; 37: 1637-55.

Storey E, Beal MF. Neurochemical substrates of rigidity and chorea in Huntington's disease. Brain 1993; 116: 1201-22.

Surmeier DJ, Reiner A, Levine MS, Ariano MA. Are neostriatal dopamine receptors co-localized? [see comments]. [Review]. Trends Neurosci 1993; 16: 299-305. Comment in: Trends Neurosci 1994; 17: 2-4; discussion 4-5.

Surmeier DJ, Reiner A, Levine MS, Ariano MA. Neostriatal dopamine receptors (letter). Trends Neurosci 1994; 17: 4-5.

Thompson PD, Berardelli A, Rothwell JC, Day BL, Dick JPR, Benecke $R$, et al. The coexistence of bradykinesia and chorea in Huntington's disease and its implications for theories of basal ganglia control of movement. Brain 1988; 111: 223-44.

Turjanski N, Burn DJ, Lammertsma AA, Dolan R, Harding AE, Quinn $N$, et al. PET studies on $D_{1}$ and $D_{2}$ receptor status in chorea [abstract]. Neurology 1993; 43 (4 Suppl 2): A333.

Vonsattel JP, Myers RH, Stevens TJ, Ferrante RJ, Bird ED, Richardson EP Jr. Neuropathological classification of Huntington's disease. J Neuropathol Exp Neurol 1985; 44: 559-77.

Wienhard K, Coenen HH, Pawlik G, Rudolf J, Laufer P, Jovkar $S$, et al. PET studies of dopamine receptor distribution using $\left[{ }^{18}\right.$ F]fluoroethylspiperone: findings in disorders related to the dopaminergic system. J Neural Transm Gen Sect 1990; 81: 195-213.

Wong DF, Kinks JM, Wagner HN, Folstein SE, Suneja S, .Dannals $\mathrm{RF}$, et al. Dopamine and serotonin receptors measured in vivo in Huntington's disease with $\mathrm{C}-11 \mathrm{~N}$-methylspiperone PET imaging [abstract]. J Nucl Med 1985; 26 Suppl: P107.

Young AB, Shoulson I, Penney JB, Starosta-Rubinstein S, Gomez $F$, Travers $H$, et al. Huntington's disease in Venezuela: neurologic features and functional decline. Neurology 1986; 36: 244-9.

Received December 29, 1994. Accepted January 30, 1995 